\title{
Feminist Encounters with the Medical Humanities
}

\author{
Sherri L. Foster ${ }^{1}$, Jana Funke ${ }^{2 *}$ \\ Published: September 27, 2018
}

\section{INTRODUCTION}

This special issue of Feminist Encounters invites scholars from different disciplines and countries to explore the relationship between feminism and the medical humanities. Broadly speaking, the medical humanities seek to create dialogues between the humanities and biomedical research and practice. Feminism, in its intellectual and political commitments, has long informed this endeavour. Feminist approaches have made it possible to challenge modes of oppression inscribed in biomedical sciences. They have helped to develop alternative understandings of health, illness, and the body, and to identify intersections between the humanities and biomedicine. Whereas some scholars in the medical humanities have explicitly acknowledged their debts to feminism (e.g. Fitzgerald and Callard, 2016; Whitehead and Wood, 2016), this issue offers the first targeted exploration of connections between both fields.

This is a timely and necessary project. The medical humanities are not new, as Jo Winning reminds us in her article in this issue: the term was first used in 1947, and the different interventions subsumed under this banner have even longer histories. Yet, this special issue is published at a time in which degree courses, research institutes, funding streams, job posts, and publications dedicated to the field continue to proliferate in the US, the UK and other European countries. Related areas of inquiry, such as the medical and health humanities, are emerging in South Africa, as discussed by Carla Tsampiras and Alex Müller in this issue. As such, this special issue addresses questions that are currently being asked with an increasing sense of 'urgency' (Whitehead and Woods, 2016: 14) and self-reflexivity (e.g. Atkinson et al., 2015; Hurwitz, 2013; Shapiro, 2012).

As editors of this special issue, we encouraged authors to articulate a wide range of responses to these debates. Since we are located on two different continents (Foster in the US and Funke in the UK), we are well aware that developments in the medical humanities have taken different shape across the Atlantic: in the US, programmes are based largely in medical education, while in the UK there has been a move towards a more expansive vision of the field, as we shall explore. Given the international remit of the journal, Feminist Encounters, we were interested in seeing how international contributors would engage with these developments. When working with the authors, who are located in Canada, Finland, the UK, and South Africa, we stressed that we were not looking for a specific definition of the medical humanities. We did, however, ask them to discuss how their feminist scholarship resonated with current debates in and about the field. This Introduction identifies some of the key ways in which the authors of the first seven articles in this issue articulate their feminist encounters with the medical humanities.

Over the last two decades, scholars have increasingly sought to move away from the idea that the humanities should act as a 'supportive friend' (Brody, 2011) or passive 'handmaiden' to medicine (Bleakley, 2015: 2). As early as 2000, Jane MacNaughton argued against a 'use value' model of the humanities, insisting that the humanities have an 'intrinsic value in their own right' (24) and are not merely a tool to train more empathetic doctors. Efforts to reframe the relationship between the humanities and biomedicine have found expression in the development of the 'critical medical humanities', spearheaded by academics in the UK (Viney et al., 2015; Whitehead and Woods, 2016). In their introduction to the Edinburgh Companion to the Critical Medical Humanities, editors Ann Whitehead and Angela Woods call on scholars to move beyond the 'primal scene' (2016: 2) of the clinical encounter between doctor and patient. They present a model that encompasses medical education and clinical practice, but also explores 'new scenes and sites that may be equally important to our understandings of health and illness' (2016: 2). This approach opens up a broader understanding of the field that includes far-reaching theorisations of illness, health, the body, materiality, and the human.

1 Associate Professor of English, Chesapeake College, USA

2 Senior Lecturer in Medical Humanities, Department of English and Film, University of Exeter, UNITED KINGDOM

*Corresponding Author: j.funke@exeter.ac.uk 
One way in which feminism has shaped these debates is by challenging forms of bias and intersectional oppression implicated in biomedicine (e.g. Fausto-Sterling, 2000; Jordan-Young, 2011; Longino and Doell, 1983; Tiefer, 1995). The alleged objectivity of the biomedical sciences and their supposed freedom from contextual values have been contested by feminist science studies scholars among others (e.g. Alcoff and Potter, 1993; Antony and Witt, 1993; Code, 1991 and 2006). Several authors in this special issue mobilise feminist sensibilities for these purposes. Bee Hughes, in her article 'Challenging Menstrual Norms in Online Medical Advice: Deconstructing Stigma Through Entangled Art Practice', reveals the limitations of online medical advice concerning menstruation, which fails to do justice to the diverse ways in which women, non-binary, and trans people experience menstruation. Situating her work in the context of menstrual activism, Hughes combines her critical analysis of medical online advice with a discussion of her own autobiographically informed creative practice as an artist. Hughes's article demonstrates how feminist approaches can reveal oversights inherent in some biomedical accounts of the body. It also stands in the feminist tradition of championing alternative modes of expression, including the creative arts, to understand embodied experience.

The struggles involved in challenging conventional notions of expertise to make space for seemingly illegitimate forms of knowledge, connect feminism and the medical humanities (Pattison, 2003). This is shown by Carla Tsampiras and Alex Müller in their article 'Overcoming "Minimal Objectivity" and "Inherent Bias": Ethics and Understandings of Feminist Research in a Health Sciences Faculty in South Africa'. The co-authors, a crossdisciplinary team of feminist researchers at a South African university, reflect upon the problems they faced when trying to obtain ethical approval for a new module on intersectional identities aimed at medical students. Because the module blurred traditional divisions between theory, research and creative practice, it was seen by the university ethics committee to lack 'minimal objectivity' and display 'inherent bias'. Tsampiras and Müller discuss how they responded to this challenge in order to create a space for 'disciplinary curiosity' and 'epistemic generosity'. The article speaks powerfully to the personal and professional frustrations that arise when creating counter-cultures of knowledge. It further shows that conversations need to take place between scholars in feminist studies and the medical humanities to understand the forms of labour and risk-taking involved in pushing against conventional epistemological traditions (Callard and Fitzgerald, 2015: 112-128; Viney et al., 2015).

Concerns about illegitimate knowledges and practices are also central to Ben Kasstan's and Sarah Crook's article 'Reproductive Rebellions in Great Britain and the Republic of Ireland: Contemporary and Past Abortion Activism and Alternative Sites of Care'. Combining historical and anthropological perspectives, the co-authors offer a comparative discussion of feminist protest movements against abortion legislation in 1970s and 1980s Britain and present-day Ireland. The article draws attention to the ways in which state legislation regulates women's access to medical care. Kasstan and Crook explore women's 'reproductive rebellions' against state domination, showing how women claimed self-governance of their bodies through unorthodox knowledges and practices of care. The article is explicitly presented as a 'provocation for the medical humanities to intervene in global health debates around sexual and reproductive rights'. This raises important questions: what counts as legitimate means of conducting research to achieve change? How is research that might be classified as a form of protest or activism judged? Answers to these questions will differ depending on scholars' disciplinary affiliations and the epistemic values inherent in them. Feminist work on interestedness and partiality (e.g. Collins, 1990; Harding, 1993 and 2004; Wylie, 2012) should play a crucial role in shaping these debates. Such scholarship can also inform research that seeks to break down conventional notions of expertise, for instance, by producing collaborative or co-produced research with non-academic partners (Ellis, 2017; Hinchliffe et al., 2017; Palmer et al., 2018).

If feminism has played an integral role in enabling scholars to challenge allegedly objective or apolitical forms of knowledge, especially with regard to biomedical science, feminists have also developed alternative stances to engage more constructively with science and medicine. Material feminists maintain that the strong focus on language and culture within much Western feminist thought has created an impasse that 'makes it nearly impossible for feminism to engage with medicine or science in innovative, productive, or affirmative ways' (Alaimo and Hekman, 2008: 4; see also Squier and Littlefield, 2004; Hird, 2004). To address this problem, feminist science scholars like Lynda Birke (2000), Karen Barad (2007), Donna Haraway (2004) and Elizabeth A. Wilson (2015) have developed approaches that incorporate insights from science and medicine to investigate embodiment and materiality. The refusal to separate language and culture from the biomedical sciences provides an understanding of 'the human, nonhuman, technological, and natural as agents that jointly construct the parameters of our common world' (Alamo and Hekman, 2008: 5). For Haraway, the 'material-discursive' (2004) and 'natureculture' (2003) cannot be separated. Barad offers the term 'intra-action' to capture 'the mutual constitution of entangled agencies', recognising 'that distinct agencies do not precede, but rather emerge through, their intra-action' (2007: 33). As feminist scholars have argued for years, nature and culture, human and nonhuman, discourse and materiality do not simply interact as separate entities, but are mutually dependent from the very start.

As Barad suggests, this approach makes it possible to 'foster constructive engagements across (and a reworking of) disciplinary boundaries' (2007: 25). It is not surprising, then, that material feminism in general, and Barad's 
concept of 'entanglement' in particular, have become key to the critical medical humanities (e.g. Fitzgerald and Callard, 2016; Viney et al., 2015). These feminist intellectual traditions have offered a different starting point for critical investigations and have helped scholars to move beyond antagonistic stances that pit the humanities against the biomedical sciences (Viney et al., 2015: 3). Several authors in this special issue engage with Haraway and Barad and draw on Felicity Callard's and Des Fitzgerald's (2016) theorisation of entanglement. Their work is central to Venla Oikkonen's article on 'Partial Immunities: Rethinking Communities and Belonging Through Viral Memories of Influenza', for example. Through an examination of biomedical, political and cultural debates around influenza vaccines, Oikkonen puts pressure on the notion of immunity, which is often associated with personal strength, bodily autonomy and health. Instead, she uses the concept of partial immunities to demonstrate that immunity is never fully achievable. Moreover, partial immunities are only produced as a result of past infections, which further calls into question binary understandings of health and illness. The ways in which influenza moves across human and non-human bodies, communities, and spaces (past and present) reveals complex entanglements that require a self-reflexive engagement with the humanities and the biomedical sciences.

Related questions regarding the human subject cut across various feminist projects and offer another site of productive exchange with the medical humanities. Different branches of feminist thought (including black, postcolonial, queer and posthumanist feminisms) have troubled conceptions of the autonomous humanist subject and have provided alternative conceptions of key philosophical categories including subjectivity, agency, resistance, or willfulness (e.g. Ahmed, 2014; Braidotti, 1994; Butler, 1990; Spivak, 1988). Such feminist scholarship speaks to a range of issues central to the medical humanities, including patient agency, the constitutive power of diagnostic categories, and the regulatory and enabling function of treatment regimes. It is also relevant to ongoing debates in narrative medicine. This subfield has sought to improve clinical practice by training doctors in narrative competence, a skill that is meant to allow clinicians to understand better patients' experiences of illness and to articulate their own experiences of caring for the sick (e.g. Charon, 2006; Frank, 1995; Greenhalgh and Hurwitz, 1998). Woods has influentially argued against the associated valorisation of narrative and the uncritical assumption of a humanist subject capable of expressing their experiences through narrative. She challenges the idea that 'narrative is necessarily coextensive with (...) subjective experience, (...) psychological health and indeed (...) humanity' (2011: 1). These important issues are taken up by Sophie Jones in her article 'The Biodrag of Genre: History and Resistance in Paul B. Preciado's Testo Junkie: Sex, Drugs, and Biopolitics in the Pharmacopornographic Era'. In Testo Junkie, Preciado gives an account of his self-experiments with synthetic testosterone. He draws attention to the ways in which gendered and sexual subjectivities are materially produced through technologies, especially drugs and pornography. Engaging with queer theory and trans feminism, Jones analyses the juxtapositions of genre in Testo Junkie. She argues that the text's revolutionary rhetoric relies on a reductive understanding of agency and resistance, since the revolutionary future it hails is achieved by a disconnect from the 'temporal drag' of the past. Jones demonstrates how closer attention to genre can add greater complexity to investigations of narrative in the medical humanities: generic conventions play a significant role in determining strategies of self-representation, as is evident in regard to trans healthcare protocols. These often require trans people to present rigid narratives of gender coherence in clinical contexts. In addition, however, Jones argues that the possibility to transform genre also means that narrative can serve to unravel stable conceptions of the human, calling into question who counts as a subject and what registers as agency or resistance in the first place.

While Jones shows how these broader questions relate to clinical practice, some voices have argued that wideranging theorisations of the human, the body, and agency are too far removed from a practical focus on clinical experience and potentially too difficult to communicate to medical students and practitioners (Downie, 2016). Jo Winning takes up these concerns in her article 'Learning to Think With: Feminist Epistemology and the PracticeBased Medical Humanities'. Winning engages directly with current contestations around the expansion of the medical humanities beyond the the clinical encounter. She argues that it is unhelpful to ask whether scholarship in the field should speak directly to medical culture or not, since this question is based on a problematic separation between theory (associated with the humanities) and practice (associated with medicine). Feminism can help to reframe this debate, because feminist thinkers have developed important tools to reconceptualise the division between theory and practice. Drawing on the work of Vinciane Despret, Haraway and Isabelle Stengers, Winning demonstrates how feminism - in its emphasis on the embodied, the corporeal, and the material - can open up an alternative practice-based conceptualisation of the medical humanities that resists the very distinction between thought and practice. The article mobilises this approach to work through the recent case of Dr. Hadiza BawaGarba in the UK. It demonstrates how feminist thought can open up a 'reflexive praxis' that refocuses attention on clinical practice.

In contrast, other contributors explicitly welcome the broadening out of the medical humanities beyond the clinical. Whereas Winning argues that feminist scholarship reinvigorates interest in clinical practice, Annmarie Adams, in her article 'Encountering Maude Abbot', makes the equally convincing case that feminist scholars need to call into question what counts as a 'medical site' (Whitehead and Woods, 2016: 22) and step outside the confines 
of the hospital. This, Adams suggests, can offer important opportunities to explore links between feminist history, feminist life writing and the medical humanities. Her article revises existing biographical accounts of late nineteenth- and early twentieth-century Canadian cardiologist Maude Abbott by combining insights drawn from material culture studies, feminist art history, and architectural history. Adams demonstrates how these methods allow scholars to explore new sites and objects of inquiry, including the medical museum and material artefacts. This is of particular relevance for the feminist medical humanities, since it is a means to discover non-traditional spaces and forms of expertise that were central to the lives of women like Adams. In this regard, moving beyond the clinical sphere can be seen as a feminist endeavour in and of itself.

Collectively, the seven articles in this special journal issue demonstrate the far-reaching contributions feminism has made to the medical humanities so far. They also show how feminist approaches can intervene in intensifying debates about the scope and purpose of the field. As such, we hope that the articles will inspire further academics, activists, artists, and healthcare providers to seek their own feminist encounters with the medical humanities.

The articles edited by Funke and Foster are published together with two articles on Japanese sexualities that appear in the final section of the journal. Rika Tsjuji's article 'Sexless Marriage in Japan as Women's Political Resistance' investigates why Japanese women choose not to have sex in heterosexual marriage. Drawing on the work of Judith Butler, Tsjuji argues that this choice needs to be seen as a political act of resistance against historically enshrined heterosexual gender roles. Through an analysis of these historical traditions, the article demonstrates that refusing to have sex allows Japanese women to assert agency. This refusal serves to expand conventional ideals of heterosexual femininity in Japanese society. The second article, 'Mishima Yukio and the Homoeroticisation of the Emperor of Japan' by Kazuyoshi Kawasaka, explores queer homoerotic politics in the works of twentieth-century Japanese author and actor Mishima Yukio. Kawasaka challenges existing accounts of Mishima's life and art, which display homophobic bias and have failed to situate his work in wider social and historical contexts. In contrast, the article investigates Mishima's far-right politics and engagement with the Japanese emperor system. It argues that Mishima appropriated the figure of the emperor to create a space for male homoerotic desires within Japanese national politics. Together, these two articles offer new insights into feminist and queer strategies of resistance that are central to the emergence of alternative sexualities in Japan.

\section{ACKNOWLEDGEMENTS}

Foster and Funke are joint and equal authors of this Introduction. Funke acknowledges support from the Wellcome Trust (NC106654/Z/14/Z and 106653/Z/14/Z). Both editors would like to acknowledge the editorial team at Lectito. They are grateful to the peer reviewers who gave generously of their time and expertise. Most importantly, enormous thanks are due to the authors of the articles in this issue.

\section{REFERENCES}

Ahmed, S. (2014). Willful Subjects. Durham: Duke University Press. https://doi.org/10.1215/9780822376101

Alaimo, S. and Hekman, S. J. (eds.) (2008). Material Feminisms. Bloomington: Indiana University Press.

Alcoff, L. and E. Potter (eds.) (1993). Feminist Epistemologies. New York: Routledge.

Antony, L. M. and Witt, C. (eds.) (1993). A Mind of One's Own: Feminist Essays on Reason and Objectivity. Boulder: Westview Press.

Atkinson, S., Evans, B., Woods, A. and Kearns, R. (2015). 'The Medical' and 'Health' in a Critical Medical Humanities. Journal of Medical Humanities, 36(1), 71-81. https:/ / doi.org/10.1007/s10912-014-9314-4

Barad, K. M. (2007). Meeting the Universe Halfway: Quantum Physics and the Entanglement of Matter and Meaning. Durham: Duke University Press. https:/ / doi.org/10.1215/9780822388128

Birke, L. I. A. (2000). Feminism and the Biological Body. New Brunswick: Rutgers University Press.

Bleakley, A. (2015). Medical Humanities and Medical Education: How the Medical Humanities Can Shape Better Doctors. London: Routledge.

Braidotti, R. (1994). Nomadic Subjects: Embodiment and Sexual Difference in Contemporary Feminist Theory. New York: Columbia University Press.

Brody, H. (2011). Defining the Medical Humanities: Three Conceptions and Three Narratives. Journal of Medical Humanities, 32(1), 1-7. https://doi.org/10.1007/s10912-009-9094-4

Butler, J. (1990). Gender Trouble: Feminism and the Subversion of Identity. New York: Routledge.

Callard, F. and Fitzgerald, D. (2015). Rethinking Interdisciplinarity across the Social Sciences and Neurosciences. Basingstoke: Palgrave Macmillan. https:// doi.org/10.1057/9781137407962

Charon, R. (2006). Narrative Medicine: Honoring the Stories of Illness. Oxford: Oxford University Press.

Code, L. (1991). What Can She Know? Feminist Theory and the Construction of Knowledge. Ithaca: Cornell University Press. 
Code, L. (2006). Ecological Thinking: The Politics of Epistemic Location. Oxford: Oxford University Press. https://doi.org/10.1093/0195159438.001.0001

Collins, P. H. (1990). Black Feminist Thought: Knowledge, Consciousness, and the Politics of Empowerment. Boston: Unwin Hyman.

Downie, R. (2016). Medical Humanities: Some Uses and Problems. The Journal of the Royal College of Physicians of Edinburgh, 46, 288-294. https://doi.org/10.4997/jrcpe.2016.416

Ellis, R. (2017). Heritage and Stigma: Co-Producing and Communicating the Histories of Mental Health and Learning Disability. Medical Humanities, 43(2), 92-98. https:// doi.org/10.1136/medhum-2016-011083

Fausto-Sterling, A. (2000). Sexing the Body: Gender Politics and the Construction of Sexuality. New York: Basic Books.

Fitzgerald, D. and Callard, F. (2016). Entangling the Medical Humanities, in A. Whitehead, A. Woods, S. J. Atkinson, J. Macnaughton and J. Richards (eds.), The Edinburgh Companion to the Critical Medical Humanities (pp. 35-49). Edinburgh: Edinburgh University Press.

Frank, A. W. (1995). The Wounded Storyteller: Body, Illness, and Ethics. Chicago: University of Chicago Press. https://doi.org/10.7208/chicago/9780226260037.001.0001

Greenhalgh, T. and Hurwitz, B. (1998). Narrative-Based Medicine: Dialogue and Discourse in Clinical Practice. London: BMJ Books.

Haraway, D. J. (2003). The Companion Species Manifesto: Dogs, People, and Significant Otherness. Chicago: Prickly Paradigm Press.

Haraway, D. J. (2004). The Haraway Reader. New York: Routledge.

Harding, S. G. (1993). Rethinking Standpoint Epistemology: What Is 'Strong Objectivity', in L. Alcoff and E. Potter (eds), Feminist Epistemologies (pp. 49-82). New York: Routledge.

Harding, S. G. (2004). The Feminist Standpoint Theory Reader: Intellectual and Political Controversies. New York: Routledge.

Hinchliffe, S., Jackson, M. A., Wyatt, K., Barlow, A. E., Barreto, M., Clare, L., Depledge, M. H., Durie, R., Fleming, L. E., Groom N., Morrissey, K., Salisbury, L. and Thomas, F. (2018). Healthy Publics: Enabling Cultures and Environments for Health. Palgrave Communications, 4(57), 1-10. https://doi.org/10.1057/s41599-018-0113-9

Hird, M. J. (2004). Sex, Gender, and Science. Basingstoke: Palgrave Macmillan. https://doi.org/10.1057/9780230510715

Hurwitz, B. (2013). Medical Humanities: Lineage, Excursionary Sketch and Rationale. Journal of Medical Ethics, 39, 672-674. https://doi.org/10.1136/medethics-2013-101815

Jordan-Young, R. M. (2010). Brain Storm: The Flaws in the Science of Sex Differences. Cambridge: Harvard University Press.

Longino, H. and Doell, R. (1983). Body, Bias, and Behavior: A Comparative Analysis of Reasoning in Two Areas of Biological Science. Signs: Journal of Women in Culture and Society, 9, 206-227.

Macnaughton, J. (2000). The Humanities in Medical Education: Context, Outcomes and Structures. Medical Humanities, 26, 23-30. https://doi.org/10.1136/mh.26.1.23

Palmer, V. J., Weavell, W., Callander, R., Piper, D., Richard, L., Maher, L., Boyd, H., Herman, H., Furler, J., Gunn, J., Ledema, R. and Robert, G. (2018). The Participatory Zeitgeist: An Explanatory Theoretical Model of Change in an Era of Coproduction and Codesign in Healthcare Improvement. Medical Humanities, 0, 1-11. https://doi.org/10.1136/medhum-2017-011398

Pattison, S. (2003). Medical Humanities: A Vision and Some Cautionary Notes. Medical Humanities, 29(1), 33-36. https://doi.org/10.1136/mh.29.1.33

Shapiro, J. (2012). Whither (Whether) Medical Humanities? The Future of Humanities and Arts in Medical Education. Journal for Learning through the Arts, 8(1), 1-24.

Spivak, G. C. (1988). Can the Subaltern Speak? In C. Nelson and L. Grossberg (eds.), Marxism and the Interpretation of Culture (pp. 271-313). Basingstoke: Macmillan Education. https://doi.org/10.1007/978-1-349-19059-1_20

Squier, S. and Littlefield, M. M. (eds.) (2004). Feminist Theory and/of Science - Special Journal Issue. Feminist Theory, 5(2). https://doi.org/10.1177/1464700104045403

Tiefer, L. (1995). Sex is Not a Natural Act and Other Essays. Boulder: Westview Press.

Viney, W., Callard, F. and Woods, A. (2015). Critical Medical Humanities: Embracing Entanglement, Taking Risks. Medical Humanities, 41, 2-7. https:// doi.org/10.1136/medhum-2015-010692

Whitehead, A. and Woods, A. (2016). Introduction, in A. Whitehead, A. Woods, S. J. Atkinson, J. Macnaughton and J. Richards (eds), The Edinburgh Companion to the Critical Medical Humanities (pp. 1-31). Edinburgh: Edinburgh University Press. https://doi.org/10.2307/j.ctt1t89dh8.6

Wilson, E. A. (2015). Gut Feminism. Durham: Duke University Press. https://doi.org/10.1215/9780822375203 
Woods, A. (2011). The Limits of Narrative: Provocations for the Medical Humanities. Medical Humanities, 37, 7378. https://doi.org/10.1136/medhum-2011-010045

Wylie, A. (2012). Feminist Philosophy of Science: Standpoint Matters. Proceedings and Addresses of the American Philosopby Association, 86(2), 47-76.

Citation: Foster, S. L. and Funke, J. (2018). Feminist Encounters with the Medical Humanities. Feminist Encounters: A Journal of Critical Studies in Culture and Politics, 2(2), 14. https://doi.org/10.20897/femenc/3882

Copyright ( $(2018$ by Author/s and Licensed by Lectito BV, Netherlands. This is an open access article distributed under the Creative Commons Attribution License which permits unrestricted use, distribution, and reproduction in any medium, provided the original work is properly cited. 